\title{
SURVEYING FOR RANAVIRUS IN GREEN FROGS (LITHOBATES CLAMITANS) AT FIVE LOCATIONS IN INDIANA
}

\author{
MEGAN E. WINZELER ${ }^{1,2,3}$, ROD N. WILLIAMS ${ }^{1}$ AND STEVEN J. A. KIMBLE ${ }^{1}$ \\ ${ }^{1}$ Forestry and Natural Resources Department, Purdue University, West \\ Lafayette, Indiana 47907 \\ 2Present address: Savannah River Ecology Lab, University of Georgia, \\ P.O. Drawer E, Aiken, SC 29802 \\ ${ }^{3}$ Author for correspondence: Telephone: (812)-746-9511; e-mail: me- \\ ganwinzeler@gmail.com
}

\begin{abstract}
Ranaviruses are an emerging pathogen within the United States that infects amphibians, reptiles, and fish. A Frog Virus 3-like (FV3) ranavirus has been detected at only two locations in Indiana; however, there have been few attempts to broadly sample for ranaviruses to determine their distribution across the state. This knowledge is necessary for the continued management and conservation of native amphibian populations. Our objective was to assess the occurrence of FV3-like ranaviruses in larval Green Frog (Lithobates clamitans) populations at five sites located in different regions of Indiana. Tissue samples were collected from 166 individuals and were assayed using both conventional and qPCR methods. We did not detect the presence of any FV3-like ranaviruses at any of the five sites with either PCR method, suggesting the possibility that at these sites, FV3-like ranaviruses may not be present. However, continued sampling should be carried out to monitor the status of the presence of ranaviruses in this portion of the Midwest.
\end{abstract}

INTRODUCTION

Throughout the world, amphibian, reptile, and fish populations are showing declines due to a variety of factors including habitat loss and fragmentation, pollution, invasive species, and the spread of infectious diseases (Ouellet et al., 2005; Blaustein et al., 2005). Contagious diseases have caused well-documented and widespread population extirpations and even species extinctions in the last few decades, especially due to the fungus Batrachochytrium dendrobatidis (Stuart et al. 2004) and ranaviruses (Price et al. 2014; Duffus et al., 2015). The emerging pathogen Ranavirus has proven to be highly virulent, contributing to die-offs in $>30$ states and in at least 105 amphibian species worldwide (Duffus et al., 2015) and may represent serious threats to wild populations (Teacher et al., 2010; Price et al., 2014; Earl and Gray 2014). Mortality rates due to ranaviruses in free-ranging amphibians can be greater than $90 \%$, presenting a significant threat to both endangered and stable populations (Miller et al., 2007). Frog Virus 3 (FV3) is the type strain of ranaviruses (Chinchar 2002) with many species of ranaviruses isolated from around the world (Hyatt et al., 2000). FV3-like ranaviruses infect the internal organs like the liver and kidneys of larval and adult amphibians (Miller et al., 2011). Controlled laboratory experiments have demonstrated that susceptibility to ranavirus infection and disease outcomes (e.g., morbidity, mortality) vary greatly across host species (Duffus et al., 2008; Schock et al., 2008; Hoverman et al., 2011).

Recently, Currylow et al., (2014) found wild ranavirus-infected larval amphibians and Eastern Box turtles (Terrapene carolina carolina) in south-central Indiana. A separate outbreak has also been documented in $T$. c. carolina in the state (Kimble et al., 2014). These studies were restricted to two locations and are the first documented outbreaks in the state, leaving the distribution of FV3-like infections across Indiana largely unknown. Because ranaviruses have been linked to mass mortality events across the country, it is important to broaden our understanding of the range of FV3-like ranaviruses in Indiana.

The Green Frog (Lithobates clamitans) occurs naturally throughout most of the eastern United States in semi-permanent to permanent lentic habitats. In relation to other amphibians, L. clamitans has a relatively high dispersal capacity and protracted larval stages (Martof 1953); making this species an ideal sentinel for estimating occurrence of FV3-like ranaviruses. Furthermore, field studies have documented $L$. clamitans as a carrier of FV3 and FV3-like ranaviruses (Gray et al., 2009; Hoverman et al., 2012; Forzán and Wood, 2013) and thus can serve as an indicator species for ranavirus occurrence at amphibian breeding sites. 
The distribution and presence of FV3-like ranaviruses in Indiana is largely undocumented. In this study, we used conventional and quantitative PCR ( $\mathrm{PPCR}$ ) to determine the presence of infection at five sites throughout Indiana. While our study does not constitute an exhaustive survey of the state, it will be useful for property managers and scientists in order to increase our ability to effectively manage disease in local amphibian populations within Indiana.

\section{METHODS}

Field Sampling - Lentic habitats located across five locations in Indiana (Figure 1) were chosen to maximize the geographic extent of sampling within the state. All five locations are on Purdue Agriculture Centers (PAC) properties. All sites are permanent wetlands with established $L$. clamitans populations (Winzeler, pers. obs.).

Tadpoles were collected using minnow trap arrays, which were checked twice daily. Two-day sampling periods occurred from August to October 2012 with a goal of 30 individuals per location between Gosner stage 24-26 (Gosner 1960). Individuals were euthanized on site immediately after capture, by placing tadpoles in a $3 \%$ solution of neutral buffered tricaine methanesulfnoate (MS-222; Argent Laboratories, Redmond, WA) for 30 minutes. Before being moved to a new site, all sampling equipment was scrubbed with a $10 \%$ bleach solution (Bryan et al., 2009) and rinsed with water to reduce contamination from site to site. Individuals at each site were euthanized in the same container using the same solution; however, fresh solution was made at each site. We recognize that trapping multiple individuals in traps or euthanizing individuals in the same solution could cause cross-contamination of positive individuals and negative individuals, resulting in false detection rates. However, we do not feel this affected our results. All individuals were identified to species by examining mouthparts (e.g., labial tooth rows; Hoverman et al., 2015) under a 40x dissecting scope and then stored

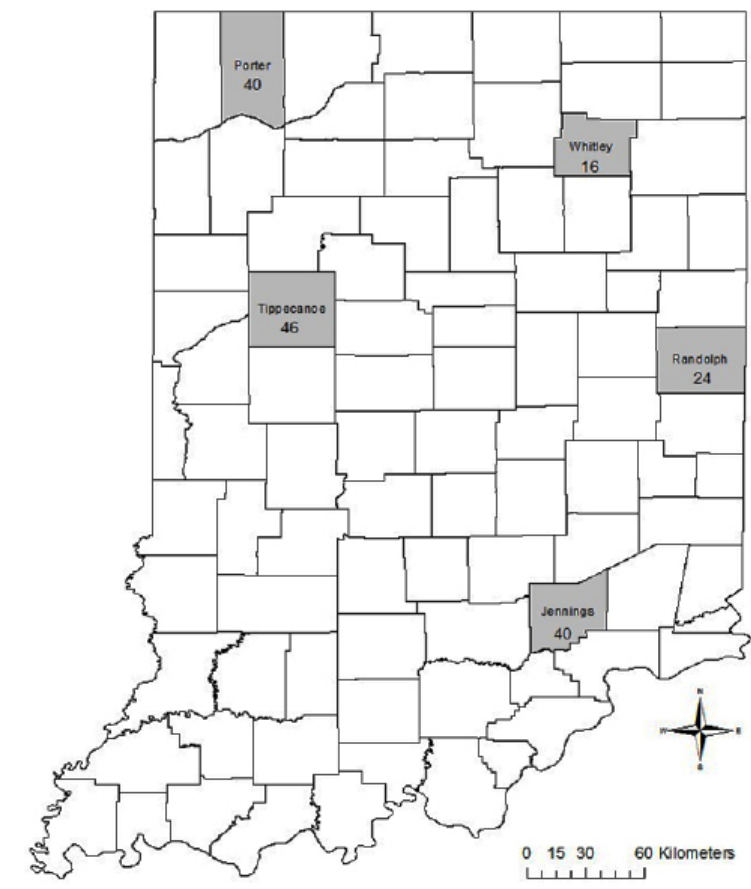

Figure 1. Five locations sampled for FV3-like ranaviruses in Indiana and with the number of individuals sampled at each site below the county name. in individual $50 \mathrm{~mL}$ conical tubes containing a $70 \%$ ethanol solution. Liver tissue was dissected under aseptic conditions in a BioSafety Hood using both $10 \%$ bleach and UV light sterilized equipment and placed in $70 \%$ ethanol in 1.5 $\mathrm{mL}$ microcentrifuge tubes.

Laboratory Methodology - Liver tissue samples were used for FV3-like ranavirus testing (Greer et al., 2005; Pearman et al., 2004). Tissue samples were individually stored in $70 \%$ ethanol at $-20^{\circ} \mathrm{C}$ prior to DNA extraction. Liver tissues were lysed in $500 \mu \mathrm{L}$ of $1 \times$ lysis buffer $(0.1 \mathrm{M}$ Tris- $\mathrm{HCl}, 0.01 \mathrm{M}$ EDTA, $0.1 \mathrm{M} \mathrm{NaCl}, 1 \% \mathrm{SDS}), 25 \mu \mathrm{L}$ of proteinase $\mathrm{K}(20 \mathrm{ng} / \mu \mathrm{L})$, and $0.1 \mathrm{M} \mathrm{DTT}$ and incubated at $37^{\circ} \mathrm{C}$ overnight. A standard phenol-chloroform DNA extraction method was employed (Sambrook and Russell, 2001).

For conventional PCR assays, we followed the amplification procedures of Mao et al., (1996) to amplify a 510 bp section of the viral major capsid protein (MCP). PCR thermal profiles followed Currylow et al., (2014) on a Bio Rad My Cycler thermocycler (Bio Rad, Hercules, CA). All PCRs were prepared and conducted within a biological safety cabinet using bleach-sterilized PCR equipment. PCR products were separated using electrophoresis on $1.5 \%$ agarose gel stained with $0.2 \mu \mathrm{g} / \mathrm{mL}$ ethidium bromide. Positive controls were obtained from an individual that was known to have an infection with an FV3-like virus was used..

For quantitative PCR, primers RVMCPKim3_F (5'-TAACACGGCATACCTGGACG-3') and (5'-GATGAGATCGCTGGTGTTGC-3') RVMCPKim3_R (Kimble et al., 2014) were used to amplify a $97 \mathrm{bp}$ region of the MCP. $20 \mu \mathrm{L}$ reactions consisted of $2 \mu \mathrm{L}$ of DNA template, $10 \mu \mathrm{L}$ of $2 \times$ SSO Advanced SYBR Green Supermix (Bio Rad, Hercules, CA), 7.2 $\mu \mathrm{L}$ PCR water, and $0.8 \mu \mathrm{L}$ of each primer. Reactions were run on a CFX Real Time qPCR thermocycler (Bio Rad, Hercules, CA). The thermal profile consisted of 2 minutes at $95^{\circ} \mathrm{C}$, then 35 cycles of $95^{\circ} \mathrm{C}$ for 20 seconds followed by $65.1^{\circ} \mathrm{C}$ for 20 seconds. All plates were set up and sealed in a sterile PCR hood and amplified in a separate laboratory. Each individual sample was run in duplicate with five serially diluted standards from 10 to $10^{6}$ viral copies constructed from cultured FV3, and a negative control using sterile $\mathrm{H}_{2} \mathrm{O}$. qPCR standards were created from cultured FV3 from an outbreak in wild adult Northern Leopard Frogs (Lithobates pipiens) from Illinois and obtained from Jason Hoverman. Based on the standard curve, a reaction was considered positive when $C_{t}<32.0$.

\section{RESULTS}

There were a total of 166 individuals collected from the five sites (Figure 1). All samples were negative for FV3-like ranavirus using both conventional and quantitative PCR.

\section{DISCUSSION}

Across five sites located across Indiana, we failed to detect ranavirus infections in L. clamitans larvae. Given that ranaviruses have been detected in surrounding states including Ohio (Homan et al., 2013), Illinois (M. Allender, pers. comm.), Kentucky (Richter et al., 2013), and Michigan (S. Kimble, pers. obs.), we anticipated detecting infections. Furthermore, FV3-like viruses have already been detected in Indianan larval amphibians (Currylow et al., 2014) and T. c. carolina (Currylow et al., 2014; Kimble et al., 2014). Indiana has also experienced high levels of habitat fragmentation, which may lead to higher prevalence of wildlife disease (McCallum and Dobson, 2002). After industrialization in the mid-1800s, only $14 \%$ of Indiana's wetlands remained intact. However, degradation such as sedimentation, pollution, and altered hydrology lowers the 
quality of residual habitats (Rizkalla and Swihart, 2006). Such anthropogenic disturbance has been shown to drastically reduce biodiversity, especially in freshwater ecosystems (Dudgeon et al., 2006). Given that reduced biodiversity has been linked to increases in parasitic infection in larval amphibians (Johnson et al., 2013), infection rates should be higher in disturbed wetlands in Indiana.

Our inability to detect ranavirus infection could have been driven by several factors. A bias in sampling could have occurred, as it has been shown that mortality can be high in L. clamitans at the beginning of the larval stage (Haislip et al., 2011). Our study sampled late in the season, suggesting that individuals we sampled may have survived this early mortality event due to evasion of infection or clearing the infection prior to our sampling. Our study was also conducted at the end of summer, which decreases the likelihood of ranavirus detection due to higher temperatures in T. c. carolina (Allender et al., 2013a), but could also reflect pathogenicity due to the species and not temperature (Bayley et al., 2013). However, ideal temperatures to detect presence of the virus was between $12-32^{\circ} \mathrm{C}$ in vitro (Chinchar 2002) and in some amphibian populations, the highest prevalence of the disease is detected in the fall (Hoverman et al., 2012), which would mean our data were collected during an ideal time period.

Our sample sizes between wetlands varied greatly (Tippecanoe Co. $\mathrm{N}=46$ vs. Whitley Co. $\mathrm{N}=16$ ), which can decrease detectability of the disease particularly if the infection rate for a particular site is low or infected individuals are no longer in the population. While 46 individuals tested are a better representation of infection presence at a location, sixteen individuals may not be sufficient for detection due to previously stated reasons. At this location, fish were abundant within the wetland and could influence the amphibian population through competition and predation (Amburgey et al., 2014; Simpkins et al., 2014). Future studies focused in Indiana should increase the number of study sites ranging throughout the state with a goal sample size of $\mathrm{N}>20$ to maintain $95 \%$ confidence of detecting a low prevalence at each site. Samples should be taken during multiple seasons to more accurately represent the amphibian population of Indiana as well as the overall distribution of ranavirus in the state.

We used GPCR as well as conventional PCR methods to reduce the possibility of rejecting positive samples and to increase the likelihood of detecting low viral loads. Allender et al., (2013b) showed that qPCR can detect ranavirus when as few as 52 copies are present in the sample. In addition, adults of some herpetofauna have been shown to be carriers with no clinical signs of disease and with viral genomes sequestered in unsampled tissues or organs (Robert et al., 2007). Quantitative PCR is, however, a highly sensitive method (Kriger et al., 2006; Getchell et al., 2007) and we are confident that our results are an accurate reflection of the absence of FV3-like ranaviruses in $L$. clamitans larvae in our samples.

Ranavirus is one of the most significant wildlife diseases worldwide (Lesbarrères et al., 2012); outbreaks can move quickly (Eaton et al., 2010) and the pathogen has the potential to switch host species (Jancovich et al., 2010; Brenes et al., 2014). Further research into the exact distribution of ranaviruses in the Midwest should be conducted given its broad host range (e.g., amphibians, reptiles, fish) and possible role in populations declines (Price et al., 2014). Other species of interest in Indiana are American Bullfrogs (Lithobates catesbeiana), congenerics of L. Clamitans, that share the same habitat with a similar distribution throughout the state. T. c. carolina are a species of conser- vation concern in Indiana (Currylow et al., 2014; Kimble et al., 2014) and can also contract ranavirus. All susceptible populations within the state should be monitored for infection of FV3-like ranaviruses. Ideally, these studies should be conducted throughout the year and include multiple amphibian, reptilian, and fish species using life stages to more accurately determine the presence of this disease.

\section{AKNOWLEDGEMENTS}

The authors would like to thank Vanessa Wuerthner and Gliselle Marin for assistance in field and lab work. Jason Hoverman provided highly valuable insight, advice, and standards that aided in this study as well as an additional review of the manuscript. Amanda Duffus and three anonymous reviewers contributed greatly to the development of this manuscript. We would also like to thank the Purdue College of Agriculture for an Undergraduate Research Award and the Indiana Department of Natural Resources.

\section{LITERATURE CITED}

Allender, M.C., M.A. Mitchell, T. Torres, J. Sekowska, and E.A. Driskell. 2013a. Pathogenicity of frog virus 3like virus in Pond Slider turtles (Trachemys scripta elegans) at two environmental temperatures. Journal of Comparative Pathology. 149:356-367.

-, M.C., D. Bunick, and M.A. Mitchell. 2013b. Development and validation of TaqMan quantitative PCR for detection of frog virus 3-like virus in eastern box turtles (Terrapene carolina carolina). Journal of Virological Methods. 188:121-125.

Amburgey, S.M., L.L. Bailey, M. Murphey, E. Muths, and W.C. Funk. 2014. The effects of hydropattern and predator communities on amphibian occupancy. Canadian Journal of Zoology. 92:927-937.

Bayley, A.E., B.J. Hill, and S.W. Feist. 2013. Susceptibility of the European common frog Rana temporaria to a panel of ranavirus isolates from fish and amphibian hosts. Diseases of Aquatic Organisms. 103:171-183.

Blaustein, A.R., J.M. Romansic, E.A. Scheessele, B.A. Han, A.P. Pessier, and J.E. Longcore. 2005. Interspecific variation in susceptibility of frog tadpoles to the pathogenic fungus Batrachochytrium dendrobatidis. Conservation Biology. 19:1460-1468.

Brenes, R., M.J. Gray, T.B. Waltzek, R.P. Wilkes, and D.L. Miller. 2014. Transmission of ranavirus between ectothermic vertebrate hosts. PLoS ONE. 9 (3): e92476. DOI:10.1371/journal.pone.0092476.

Bryan, L.K., C.A. Balswin, M.J. Gray, and D.L. Miller. 2009. Efficacy of select disinfectants at inactivating Ranavirus. Diseases of Aquatic Organisms. 84:8994.

Chinchar, V.G. 2002. Ranaviruses (family Iridoviridae): emerging cold-blooded killers. Archives of Virology. 147:447-470.

Currylow, A., A.J. Johnson, and R.N. Williams. 2014. Evidence of ranavirus infections among sympatric larval amphibians and box turtles (Terrapene carolina carolina). Journal of Herpetology. 48(1):117-121.

Dudgeon, D., A.H. Arhington, M.O. Gessner, Z. Kawabata, D.J. Knowler, C. Leveque, R.J. Naiman, A. Prieur-Richard, D. Soto, M.L.J. Stiassny, and C.A. Sullivan. 2006. Freshwater biodiversity: importance, threats, status and conservation challenges. Biological Reviews. 81:163-182.

Duffus, A.L.J., B.D. Pauli, K. Wozney, C.R. Brunetti, and M. Berrill. 2008. Frog virus 3-like infections in aquatic amphibian communities. Journal of Wildlife Diseases. 44:109-120. 
Duffus, A.L.J., T.B. Waltzek, A.C. Stohr, M.C. Allender, M. Gotesman, R.J. Whittington, P. Hick, M.K. Hines, and R.E. Marschang. 2015. Distribution and host range of ranaviruses. In Ranaviruses: Lethal Pathogens of Ectothermic Vertebrates, M.J. Gray and V.G. Chinchar, (Eds). Springer Online.

Earl, J.E. and M.J. Gray. 2014. Introduction of Ranavirus to isolated wood frog populations could cause local extinction. EcoHealth. 11:581-592.

Eaton, H.E., E. Penny, and C.R. Brunetti. 2010. Antibody dependent enhancement of frog virus 3 infection. Virology Journal. 7:41.

Forzán, M.J. and J. Oodwood. 2013. Low detection of ranavirus DNA in wild postmetamorphic green frogs, Rana (Lithobates) clamitans, despite previous or concurrent tadpole mortality. Journal of Wildlife Diseases. 49:879-886.

Getchell, R.G., G.H. Groocock, V.L. Schumacher, S.G. Grimmett, G.A. Wooster, and P.R. Bowser. 2007. Quantitative polymerase chain reaction assay for largemouth bass virus. Journal of Aquatic Animal Health. 19:226-233.

Gosner, K.L. 1960. A simplified table for staging anuran embryos and larvae with notes on identification. Herpetologica. 16:183-190.

Gray, M.J., D.L. Miller, and J.T. Hoverman. 2009. Ecology and pathology of amphibian ranaviruses. Diseases of Aquatic Organisms. 87:243-266.

Greer, A.L., M. Berrill, and P.J. Wilson. 2005. Five amphibian mortality events associated with ranavirus infection in south central Ontario, Canada. Diseases of Aquatic Organisms. 67:9-14.

Haislip, N.A., M.J. Gray, J.T. Hoverman, and D.L. Miller. 2011. Development and disease: how susceptibility to an emerging pathogen changes through anuran development. PLOS ONE 6(7): e22307.

Homan, R.N., J.R. Bartling, R.J. Stenger, and J.L. Brunner. 2013. Detection of Ranavirus in Ohio, USA. Herpetological Review. 44:615-618.

Hoverman, J.T., M.J. Gray, N.A. Haislip, and D.L. Miller. 2011. Phylogeny, life history, and ecology contribute to differences in amphibian susceptibility to ranaviruses. EcoHealth. 8(3):301-319.

Hoverman, J.T., M.J. Gray, D.L. Miller, and N.A. Haislip. 2012. Widespread occurrence of ranavirus in pond-breeding amphibian populations. EcoHealth. 9:36-48

Hoverman, J.T., Z. Olson, S. LaGrange, J. Grant, and R.N. Williams. 2015. A guide to larval amphibian identification in the field and laboratory. Purdue University Extension FNR-496.

Hyatt, A.D., A.R. Gould, Z. Zupanovic, A.A. Cunningham, S. Hengstberger, R.J. Whittington, J. Kattenbelt, and B.E.H. Coupar. 2000. Comparative studies of piscine and amphibian iridoviruses. Archives of Virology. 145:301-331.

Jancovich, J.K., M. Bremont, J.W. Touchman, and B.L. Jacobs. 2010. Evidence for multiple recent host species shifts among the ranaviruses (Family Iridoviridae). Journal of Virology. 84(6):2636-2647.

Johnson, P.T.J., L. Preston, J.T. Hoverman, and K.L.D. Richgels. 2013. Biodiversity decreases disease through predictable changes in host community competence. Nature. 494:230-233.

Kimble, S.J.A., A.K. Karna, A.J. Johnson, J.T. Hoverman, and R.N. Williams. 2014. Mosquitoes as a potential vector of ranavirus transmission in terrestrial turtles. EcoHealth. 12(2):334-338.
Kriger, K.M., H.B. Hines, A.D. Hyatt, D.G. Boyle, and J. Hero. 2006. Techniques for detecting chytridiomycosis in wild frogs: comparing histology with real-time Taqman PCR. Diseases of Aquatic Organisms. 71:141-148.

Lesbarréres, D., A. Balseiro, J. Brunner, V.G. Chinchar, A. Duffus, J. Kerby, D.L. Miller, J. Robert, D.M. Schock, T. Waltzek and M. Gray. 2012. Ranavirus: past, present and future. Biological Letters. 8(4): 481-483.

McCallum, H. and A. Dobson. 2002. Disease, habitat fragmentation and conservation. Proceedings of the Royal Society B. 269:2041-2049.

Mao, J.H., T.N. Tham, G.A. Gentry, A. Aubertin, and V.G. Chinchar. 1996. Cloning, sequence analysis, and expression of the major capsid protein of the iridovirus Frog Virus 3. Virology. 216:431-436.

Martof, B. 1953. Home range and movements of the green frog, Rana clamitans. Ecology. 34:529-543.

Miller, D.L., S. Rajeev, M.J. Gray, and C.A. Baldwin. 2007. Frog virus 3 infection, cultured American bullfrogs [letter]. Emerging Infectious Diseases. 13:342-343

- M.J. Gray, and A. Storfer. 2011. Ecopathology of ranaviruses infecting amphibians. Viruses. 3:2351-2373. DOI: $10.3390 / \mathrm{v} 3112351$.

Ouellet, M., I. Mikaelian, B.D. Pauli, J. Rodrigue, and D.M. Green. 2005. Historical evidence of widespread chytrid infection in North American amphibian populations. Conservation Biology. 19:1431-1440.

Pearman, P.B. and T.W.J. Garner. 2005. Susceptibility of Italian agile frog populations to an emerging strain of Ranavirus parallels population genetic diversity. Ecological Letters. 8:401-408.

Price, S.J., T.W.J. Garner, R.A. Nichols, F. Balloux, C. Ayres, A. More-Cabello de Alba, and J. Bosch. 2014. Collapse of amphibian communities due to an introduced Ranavirus. Current Biology. 24:2586-2591.

Richter, S.C., A.N. Srayer, J.R. Strong, C.S. Kross, D.L. Miller, and M.J. Gray. 2013. High prevalence of ranavirus infection in permanent constructed wetlands in eastern Kentucky, USA. Herpetological Review. 44:464-466.

Rizkalla, C.E. and R.K. Swihart. 2006. Community structure and differential responses of aquatic turtles to agriculturally induced habitat fragmentation. Landscape Ecology. 21:1361-1375.

Robert, J., L. Abramowitz, J. Gantress, and H.D. Morales. 2007. Xenopus laevis: a possible vector of ranavirus infection? Journal of Wildlife Diseases. 43:645-652.

Sambrook, J., and D. Russell. 2001. Molecular cloning: a laboratory manual. $3^{\text {rd }}$ ed. Cold Spring Harbor Laboratory Press, USA.

Schock, D.M., T.K. Bollinger, V.G. Chinchar, J.K. Jancovich, and J.P. Collins. 2008. Experimental evidence that amphibian ranaviruses are multi-host pathogens. Copeia. 2008:133-143.

Simpkins, C.A., J.D. Shuker, G.W. Lollback, J.G. Castley and J. Hero. 2014. Environmental variables associated with the distribution and occupancy of habitat specialist tadpoles in naturally acidic, oligotrophic wetlands. Austral Ecology. 39(1):95-105.

Stuart, S.N., J.C. Chanson, N.A. Cox, B.E. Young, A.S.L. Rodrigues, D.L. Fischman, and R.W. Waller. 2004. Status and trends of amphibian declines and extinctions worldwide. Science. 306:1783-1786.

Teacher, A.G.G., A.A. Cunningham, and T.W.J. Garner. 2010. Assessing the long-term impact of Ranavirus infection in wild common frog populations. Animal Conservation. 13:514-522. 